\title{
Design and Synthesis of Novel Indolizine Analogues as COX-2 Inhibitors: Computational Perspective and in vitro Screening
}

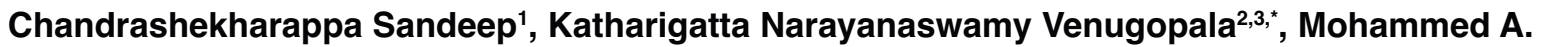 \\ Khedr $^{3,4}$, Basavaraj Padmashali5,6 ${ }^{\star}$, Rashmi Sanganna Kulkarni ${ }^{7}$, Rashmi Venugopala $^{8}$, Bharti Odhav ${ }^{2}$ \\ ${ }^{1}$ Institute for Stem Cell Biology and Regenerative Medicine, NCBS, TIFR, GKVK, Bellary Road, Bangalore-560065, INDIA. \\ ${ }^{2}$ Department of Biotechnology and Food Technology, Durban University of Technology, Durban 4001, SOUTH AFRICA. \\ ${ }^{3}$ Department of Pharmaceutical Sciences, College of Clinical Pharmacy, King Faisal University, Al-Ahsa 31982, Kingdom of \\ SAUDI ARABIA. \\ ${ }^{4}$ Department of Pharmaceutical Chemistry, Faculty of Pharmacy, Helwan University, Ein Helwan, Cairo 11795, EGYPT. \\ ${ }^{5}$ Department of Chemistry, Sahyadri Science College (Autonomous), Shimoga 577 203, INDIA. \\ ${ }^{6}$ Department of Studies and Research in Chemistry, School of Basic Sciences, Rani Channamma University, Belagavi 591 156, \\ Karnataka, INDIA. \\ ${ }^{7}$ Department of Chemistry, Jain University, Bangalore 560 019, INDIA. \\ ${ }^{8}$ Department of Public Health Medicine, University of KwaZulu-Natal, Howard College Campus, Durban 4001, SOUTH AFRICA.
}

\begin{abstract}
Design and synthesis of a new series of ethyl 7-methoxy-2-substituted-3-(substituted benzoyl) indolizine-1-carboxylates 2a-i was achieved and screened for their in vitro inhibitory activity against COX-2 enzyme. Compound $2 \mathrm{a}$ and $\mathbf{2 c}$ emerged as promising COX-2 enzyme inhibitor with $\mathrm{IC}_{50}$ of 6.56 and $6.94 \mu \mathrm{M}$ respectively from the synthesized series when compared to Celecoxib and Indomethacin as selective and nonselective standards, respectively. Computational docking study identified the possible reasons for such activity that may be due to the cis configuration of the indolizines that resulted in the most stable conformation similar to that of Indomethacin.
\end{abstract}

Key words: Cox-2 Inhibition, Indolizine Analogues, Synthesis, Characterization, Molecular Docking.

\section{INTRODUCTION}

Indolizines are bicyclic heterocyclic compounds with various promising pharmacological properties. ${ }^{1-3}$ With regard to positions there are nine non-equivalents around the bicyclic indolizine structure. Several synthetic strategies have been adopted to obtain substituted indolizine analogues with various functional groups. ${ }^{1,-7}$ Some of the biologically important natural products and synthetic pharmaceuticals contain indolizine pharmacophore as an important $N$-fused heterocycles. ${ }^{8-18}$ Accordingly, synthesis and derivatization of indolizines have attracted considerable attention of medicinal chemist over the decades. ${ }^{19-33}$ Particularly the 3 -benzoylindolizines are attractive since their derivatives have been used as pharmacologically interesting compounds and their vital role as the synthetic intermediates for 3-substituted indolizines is also apparent. ${ }^{34}$ Indolizine system is isoelectronic with indole nucleus and signifies a group of heterocyclic compounds structurally associated to purines. Several indolizine analogues have been reported for various pharmacological properties such as analgesic, ${ }^{35,36}$ anti-inflammatory, ${ }^{37}$ 5HT3 receptor antagonist, ${ }^{38}$ anticholinergic, ${ }^{39}$ anticancer, ${ }^{40-42}$ estrogen receptor binding, ${ }^{43}$ antioxidant, ${ }^{44,45}$ antimicrobial, ${ }^{46}$ antimutagenic, ${ }^{47}$ CNS depressant ${ }^{48}$ and hypoglycemic activities. $^{49,50}$ Cyclooxygenase (COX) enzyme mainly occurs in two isoforms COX-1 and COX-2 that have $60 \%$ identity of their sequence and the latter one is the key enzyme
Submission Date: 30-11-2016; Revision Date: 15-02-2017; Accepted Date: 14-03-2017 DOI: 10.5530/ijper.51.3.73 Correspondence: Katharigatta N. Venugopala, Basavaraj Padmashali, Department of Biotechnology and Food Technology, Durban University of Technology, Durban 4001, South Africa, Department of Pharmaceutical Sciences, College of Clinical Pharmacy, King Faisal University, Al-Ahsa 31982, Kingdom of SAUDI ARABIA,

(Katharigatta N. Venugopala) Department of Chemistry, Sahyadri Science College (Autonomous), Shimoga 577 203, INDIA

Department of Studies and Research in Chemistry, School of Basic Sciences, Rani Channamma University, Belagavi 591 156, Karnataka, INDIA

Tel. +27 31 3736887; Tel. +919844218894 Fax: +27 862423534 E mail: katharigattav@dut. ac.za

\&basavarajpadmashali@ yahoo.com

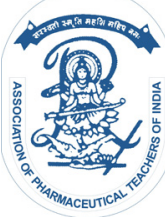

www.ijper.org 
in the biosynthetic pathway leading to the development of prostaglandins, which are mediators of inflammation. ${ }^{51}$ The conventional nonsteroidal anti-inflammatory drugs (NSAIDs) tend to exhibit unwanted side effects such as gastrointestinal, cardiovascular and renal complications. ${ }^{52}$ Literature survey reveals that the overexpression of particularly cyclooxygenases- 2 enzyme, promotes multiple events involved in tumorigenesis; in addition, several studies demonstrates that the inhibition of cyclooxygenases- 2 can delay or prevent certain forms of cancer. ${ }^{53}$

In continuation of our studies on polymorphism behavior of heterocyclic compounds $s^{54-56}$ and pharmacological screening of heterocyclic compounds for anticancer, ${ }^{40,57}$ anti-mosquito $^{58,59}$ and anti- $\mathrm{TB}^{60}$ properties, herewith we undertake design of proposed compounds based on Lipinski rule of five ${ }^{61}$ and synthesis of novel ethyl 3-(substitutedbenzoyl)-7-methoxy-2-methylindolizine1-carboxylates (Scheme-1) and screen them for in vitro COX-2 inhibitory activity. In addition, computational studies to study the conformational impact on the binding and inhibitory activity.

\section{MATERIALS AND METHODS}

\section{General chemistry}

All the commercially available chemicals were purchased from Sigma-Aldrich chemicals and all the chemical reactions were carried out in hot-air dried glass wares under nitrogen atmosphere using dry solvents. NMR (300, 400 $\mathrm{MHz}$ ) spectra were recorded at ambient temperature using $\mathrm{CDCl}_{3}$ and DMSO- $d_{6}$ as a solvent using Bruker- 400 spectrometer. Chemical shift values are measured in $\delta \mathrm{ppm}$ and were referenced with tetramethylsilane (TMS). The peak multiplicities were given as $s$, singlet; $d$, doublet; $t$, triplet; q, quartet; $m$, multiplet. LC-MS analysis was performed on Agilent LC-1200 series coupled with 6140 single quad mass spectrometer with ESI +ve and -ve mode, MS range 100-1500. Perkin Elmer CHNS analyser was used to perform elemental analysis.

\section{GENERAL PROCEDURE FOR THE SYNTHESIS OF 4-METHOXY-1-(2-(SUBSTITUTEDPHENYL)-2- OXOETHYL)PYRIDINIUM BROMIDE (1A-D)}

TO A STIRRED solution of 4-methoxypyridine $(0.0091 \mathrm{~mol})$ in dry acetone $(10 \mathrm{~mL})$, 4-substituedphenacylbromide $(0.0091 \mathrm{~mol})$ was added and at room temperature the reaction mixture was stirred for $5 \mathrm{~h}$. Completion of the reaction was checked on thin layer chromatography. The product separated was filtered, recrystallized using ethanol as solvent and dried at room temperature to afford $98-99 \%$ yield of 1-(2-(4-substituedphenyl)-2-oxoethyl)-4-methoxypyridinium bromides 1a-d.

\section{1-(2-(4-Cyanophenyl)-2-oxoethyl)-4- methoxypyridinium bromide (1a)}

Appearance: Light yellow colour solid. Yield 98\%. ${ }^{1} \mathrm{H}-\mathrm{NMR}\left(400 \mathrm{MHz}, \mathrm{DMSO}-d_{6}\right) \delta=8.96-8.94(\mathrm{~d}$, $J=7.2 \mathrm{~Hz}, 2 \mathrm{H}), 8.52-8.50(\mathrm{~d}, J=7.0 \mathrm{~Hz}, 2 \mathrm{H}), 7.90-7.88$ $(\mathrm{d}, J=7.2 \mathrm{~Hz}, 2 \mathrm{H}), 7.58-7.56(\mathrm{~d}, J=8 \mathrm{~Hz}, 2 \mathrm{H}), 6.29$ (s, 2H), 4.14 (s, 3H); LC-MS (ESI, Positive): $m / ₹:(\mathrm{M}+\mathrm{H})^{+}$: 253.2 .

\section{1-(2-(4-Fluorophenyl)-2-oxoethyl)-4- methoxypyridinium bromide (1b)}

Appearance: White colour solid. Yield 99\%. ${ }^{1} \mathrm{H}-\mathrm{NMR}$ $\left(400 \mathrm{MHz}\right.$, DMSO- $\left.d_{\sigma}\right) \delta=8.72-8.70(\mathrm{~d}, J=7.0 \mathrm{~Hz}$, $2 \mathrm{H}), 8.75-8.67(\mathrm{~d}, J=7.2 \mathrm{~Hz}, 2 \mathrm{H}), 8.30-8.27(\mathrm{~m}, 2 \mathrm{H})$, $8.13-8.10(\mathrm{t}, J=8.8 \mathrm{~Hz}, 2 \mathrm{H}), 6.28(\mathrm{~s}, 2 \mathrm{H}), 4.19(\mathrm{~s}, 3 \mathrm{H})$; LC-MS (ESI, Positive): $m / ₹:(\mathrm{M}+\mathrm{H})^{+}: 246.12$.

\section{1-(2-(4-Bromophenyl)-2-oxoethyl)-4- methoxypyridinium bromide (1c)}

Appearance: White colour solid. Yield 98\%. ${ }^{1} \mathrm{H}$ NMR $\left(400 \mathrm{MHz}\right.$, DMSO- $\left.d_{6}\right) \delta=9.10-9.08(\mathrm{~d}, J=7.2 \mathrm{~Hz}$, $2 \mathrm{H}), 8.24-8.22(\mathrm{~d}, J=7.0 \mathrm{~Hz}, 2 \mathrm{H}), 8.02-8.00(\mathrm{~d}, J=7.2$ $\mathrm{Hz}, 2 \mathrm{H}), 7.72-7.70$ (d, $J=8 \mathrm{~Hz}, 2 \mathrm{H}), 6.24$ (s, 2H), 4.15 (s, 3H); LC-MS (ESI, Positive): $m / ₹:(\mathrm{M}+\mathrm{H})^{+}: 306.2$.

\section{4-Methoxy-1-(2-(3-methoxyphenyl)-2-oxoethyl) pyridinium bromide (1d)}

Appearance: Yellow colour solid. Yield 99\%. ${ }^{1} \mathrm{H}-\mathrm{NMR}$ $(400 \mathrm{MHz}, \mathrm{DMSO}-d) \delta=9.02-9.00(\mathrm{~d}, J=7.2 \mathrm{~Hz}, 2 \mathrm{H})$, 8.54-8.52 (d, $J=7.2 \mathrm{~Hz}, 2 \mathrm{H}), 7.49-7.47(\mathrm{~d}, J=7.2 \mathrm{~Hz}$, 1H), 7.36-7.31 (t, $J=7.2 \mathrm{~Hz}, 1 \mathrm{H}), 7.15(\mathrm{~s}, 1 \mathrm{H}), 7.10-7.08$ (d, J = 7.2 Hz, 1H), 6.27 (s, 2H), 4.10 (s, 3H), 3.88 (s, $3 \mathrm{H})$; LC-MS (ESI, Positive): $m / ₹(\mathrm{M}+\mathrm{H})^{+}: 258.2$.

\section{General procedure for the synthesis of ethyl 7-acetyl-3-(substitutredbenzoyl)-2- substitutedindolizine-1-carboxylate (2a-i)}

To a stirred solution of 1-(2-(substitutedphenyl)-2-oxoethyl)4-methoxypyridinium bromide $(0.00156 \mathrm{~mol})$, in dry dimethylformamide $(15 \mathrm{~mL})$, was added ethyl propiolate $(0.00156 \mathrm{~mol})$ and $\mathrm{K}_{2} \mathrm{CO}_{3}(0.0031 \mathrm{~mol})$. At room temperature the reaction mixture was stirred for $30 \mathrm{~min}$ and reaction completion was monitored on TLC. After reaction completion, the solvent was evaporated under reduced pressure and diluted with ethyl acetate. Water and brine was used to wash organic layer and dried over sodium sulphate. The crude compound was purified by column chromatography to afford $66-80 \%$ yield of compounds 2a-i. Physicochemical constants of the characterized compounds are tabulated in Table 1. 


\section{COX-2 inhibition activity}

The title compounds 2a-i were screened for human recombinant COX-2 inhibitory activity using an enzyme immunoassay kit. $\mathrm{IC}_{50}$ is the concentration of test and standard compounds required to produce $50 \%$ inhibition of human recombinant COX-2 by means of three determinations using the enzyme linked immuno sorbent assay kit (Table 2). Significant differences were detected between treatments $\left(\mathrm{F}_{10,32}=108.7 ; \mathrm{p}<0.001\right)$. Test compound $2 \mathrm{a}$ with nitrile group on phenyl ring which is connected to indolizine nucleus through carbonyl group emerged as promising COX-2 enzyme inhibitor with $\mathrm{IC}_{50}$ of $6.56 \mu \mathrm{M}$ from the series when compared to selective (Celecoxib) and nonselective (Indomethacin) standard compounds with their inhibitory activity at 0.05 and $6.8 \mu \mathrm{M}$, respectively. Compound $2 \mathrm{c}$ exhibited moderate COX-2 enzyme inhibition activity with $\mathrm{IC}_{50}$ of $6.94 \mu \mathrm{M}$.

\section{Computational Studies}

\section{Molecular docking}

The crystal structures of COX-1 and COX-2 have sequence identity of $60 \%{ }^{68}$ The active site of both isoforms have a typical active site that have a hydrophobic long channel. Mapping of this channel illustrated that it has a number of hydrophobic residues such as Leu 384, Phe 381, Tyr 385, and Trp 387 beside other residues such as Arg 120, His 90. Non-selective NSAIDs are all bound to this hydrophobic channel by interactions of their carboxylate anionic group with the cationic guanidinium group of Arg 120 forming salt bridge. In addition, they form hydrogen bond with Tyr 355 .

The binding of Indomethacin as a non-selective COX inhibitor has shared binding mode in both COX-1 and
COX-2 hydrophobic channel in which the chloro atom at para-phenyl moiety interacts with Leu 384. The benzoyl carbonyl $\mathrm{C}=\mathrm{O}$ group is essential in hydrogen bond formation with the hydroxyl group of Ser 530 and Val 349. The phenyl part of the benzoyl moiety shared by hydrophobic interactions with Leu 384, Phe 381, Tyr 385, and Trp 387. The indole scaffold participates by a hydrophobic interactions as well with Val 349. ${ }^{68,69}$

Indomethacin has many conformations but, the cis conformation around the $\mathrm{C}=\mathrm{O}$ in which both parachloro phenyl moiety and indole moiety are oriented in the same direction has achieved higher selectivity toward COX-2 inhibition ${ }^{70}$.

The main difference between COX-1 and COX-2 binding site is the presence of hydrophilic side pocket in COX-2 only just beyond the hydrophobic channel. The selective COX-2 inhibitor Celecoxib has a hydrophilic sulfonyl amino side chain $\left(\mathrm{H}_{2} \mathrm{~N}-\mathrm{SO}_{2}\right)$ that allows the drug to fit in this hydrophilic side pocket and forming strong hydrogen bonding with His 90, Gln 192 and Arg 513. Celecoxib does not have a carboxylic group as well so, the salt bridge with Arg 120 is not found. In other words, the binding mode of non-selective COX inhibitors is different from those of selective ones due to structural basis in COX-2 isoform itself. Also. Celecoxib does not inhibit COX-1 at therapeutic concentrations effective on COX-2.

In this work, a series of novel indolizine analogues has been synthesized and tested for the COX-2 inhibition. A molecular docking of the synthesized compounds against both COX-1 and COX-2 was done to interpret their possible binding mode. According to the docking results (Table 3), the docked compounds almost have the same in silico affinity of Indomethacin. All

\begin{tabular}{|c|c|c|c|c|c|c|}
\hline Compound & $\begin{array}{l}\text { Mol formulae } \\
\text { (Mol mass) }\end{array}$ & $\mathbf{R}^{1}$ & $\mathbf{R}^{2}$ & Yield $(\%)^{a, b}$ & m.p $\left({ }^{\circ} \mathrm{C}\right)$ & $c \log P^{c}$ \\
\hline $2 a$ & $\mathrm{C}_{20} \mathrm{H}_{16} \mathrm{~N}_{2} \mathrm{O}_{4}(348)$ & 4-CN & $\mathrm{H}$ & 76 & 165 & 3.9570 \\
\hline $2 b$ & $\mathrm{C}_{21} \mathrm{H}_{18} \mathrm{~N}_{2} \mathrm{O}_{4}(362)$ & $4-\mathrm{CN}$ & $\mathrm{CH}_{3}$ & 68 & 191 & 4.4560 \\
\hline $2 c$ & $\mathrm{C}_{19} \mathrm{H}_{16} \mathrm{FNO}_{4}(341)$ & $4-\mathrm{F}$ & $\mathrm{H}$ & 79 & 118 & 4.5293 \\
\hline $2 d$ & $\mathrm{C}_{20} \mathrm{H}_{18} \mathrm{FNO}_{4}(355)$ & $4-F$ & $\mathrm{CH}_{3}$ & 72 & 137 & 5.0283 \\
\hline $2 e$ & $\mathrm{C}_{21} \mathrm{H}_{20} \mathrm{FNO}_{4}(369)$ & $4-\mathrm{F}$ & $\mathrm{C}_{2} \mathrm{H}_{5}$ & 70 & 124 & 5.5573 \\
\hline $2 f$ & $\mathrm{C}_{19} \mathrm{H}_{16} \mathrm{BrNO}_{4}(402)$ & $4-\mathrm{Br}$ & $\mathrm{H}$ & 74 & 183 & 5.2493 \\
\hline $2 g$ & $\mathrm{C}_{20} \mathrm{H}_{18} \mathrm{BrNO}_{4}(416)$ & $4-\mathrm{Br}$ & $\mathrm{CH}_{3}$ & 70 & 148 & 5.7483 \\
\hline $2 \mathrm{~h}$ & $\mathrm{C}_{20} \mathrm{H}_{19} \mathrm{NO}_{5}(353)$ & $3-\mathrm{OCH}_{3}$ & $\mathrm{H}$ & 80 & 116 & 4.4986 \\
\hline $2 \mathbf{i}$ & $\mathrm{C}_{21} \mathrm{H}_{21} \mathrm{NO}_{5}(367)$ & $3-\mathrm{OCH}_{3}$ & $\mathrm{CH}_{3}$ & 74 & 130 & 4.9976 \\
\hline
\end{tabular}


Table 2: In vitro COX-2 inhibitory activity of ethyl 7-methoxy-

3-(substitutredbenzoyl)-2-substitutedindolizine-1-carboxylate analogues $2 \mathrm{a}-\mathrm{i}$.

\begin{tabular}{|c|c|c|c|}
\hline \multirow{2}{*}{ Compound } & \multicolumn{2}{|c|}{ Substituents } & \multirow{2}{*}{ IC $_{50}(\mu \mathrm{M})^{\mathbf{a}}$} \\
\cline { 2 - 3 } & $\mathbf{R}^{1}$ & $\mathbf{R}^{\mathbf{2}}$ & \\
\hline $\mathbf{2 a}$ & $4-\mathrm{CN}$ & $\mathrm{H}$ & $6.56 \pm 0.03^{\mathrm{ab}}$ \\
\hline $\mathbf{2 b}$ & $4-\mathrm{CN}$ & $\mathrm{CH}_{3}$ & $7.24 \pm 0.03^{\mathrm{c}}$ \\
\hline $\mathbf{2} \mathbf{c}$ & $4-\mathrm{F}$ & $\mathrm{H}$ & $6.94 \pm 0.03^{\mathrm{cd}}$ \\
\hline $\mathbf{2 d}$ & $4-\mathrm{F}$ & $\mathrm{CH}_{3}$ & $7.52 \pm 0.03^{\mathrm{e}}$ \\
\hline $\mathbf{2 e}$ & $4-\mathrm{F}$ & $\mathrm{C}_{2} \mathrm{H}_{5}$ & $7.95 \pm 0.03^{\mathrm{e}}$ \\
\hline $\mathbf{2 f}$ & $4-\mathrm{Br}$ & $\mathrm{H}^{\mathrm{f}}$ & $7.27 \pm 0.03^{\mathrm{c}}$ \\
\hline $\mathbf{2 g}$ & $4-\mathrm{Br}$ & $\mathrm{CH}_{3}$ & $7.54 \pm 0.03^{\mathrm{e}}$ \\
\hline $\mathbf{2 h}$ & $3-\mathrm{OCH}$ & $\mathrm{H}_{3}$ & $7.36 \pm 0.03^{\mathrm{f}}$ \\
\hline $\mathbf{2 i}$ & $3-\mathrm{OCH}_{3}$ & $\mathrm{CH}_{3}$ & $7.35 \pm 0.03^{\mathrm{f}}$ \\
\hline Indomethacin & - & - & $6.84 \pm 0.03^{\mathrm{bd}}$ \\
\hline Celecoxib & - & - & $0.05 \pm 0.03^{\mathrm{a}}$ \\
\hline
\end{tabular}

${ }^{a} I_{50}$ value is the concentration of test and standard compounds required to produce $50 \%$ inhibition of human recombinant COX-2 by means of three determinations using the enzyme linked immuno sorbent assay kit. IC ${ }_{50}$ value not sharing the same superscript letter differ significantly $(p<0.05)$.

\begin{tabular}{|c|c|c|}
\hline \multirow{2}{*}{$\begin{array}{c}\text { Table 3: Molecular docking results of ethyl 7-meth- } \\
\text { oxy-3-(substitutred benzoyl)-2-substitutedindolizine- } \\
\text { 1-carboxylate analogues 2a-i. }\end{array}$} \\
\hline \multirow{2}{*}{ Compound } & \multicolumn{2}{|c|}{$\begin{array}{c}\text { Computational binding affinity (Kcal/ } \\
\text { mol) }\end{array}$} \\
\cline { 2 - 3 } & COX-1 & CoX-2 \\
\hline $\mathbf{2 a}$ & -6.95 & -7.51 \\
\hline $\mathbf{2 b}$ & -6.50 & -7.15 \\
\hline $\mathbf{2 c}$ & -6.75 & -7.35 \\
\hline $\mathbf{2 d}$ & -6.45 & -7.20 \\
\hline $\mathbf{2 e}$ & -6.60 & -7.30 \\
\hline $\mathbf{2 f}$ & -6.35 & -6.95 \\
\hline $\mathbf{2 g}$ & -6.30 & -6.90 \\
$\mathbf{2 h}$ & -6.25 & -6.75 \\
\hline $\mathbf{2 i}$ & -6.27 & -6.70 \\
\hline Indomethacin & -7.05 & -7.65 \\
\hline Celecoxib & -11.32 & -13.85 \\
\hline
\end{tabular}

compounds shared a common binding mode in the hydrophobic channel of COX-2 in which the substituted benzoyl moiety and the indolizine ring were oriented to the same direction. The best poses for the active compounds $\mathbf{2 a}$ and $\mathbf{2 c}$ have been superimposed on the best pose of Indomethacin as well (Figure 1).

\section{Ethyl 3-(4-cyanobenzoyl)-7-methoxyindolizine-1- carboxylate $(2 a)$}

Appearance: Yellow colour fluffy crystalline compound; IR $\left(\right.$ neat $\left.\mathrm{cm}^{-1}\right): 2227,1701,1639,1604 ;{ }^{1} \mathrm{H}-\mathrm{NMR}(300$
$\left.\mathrm{MHz}, \mathrm{CDCl}_{3}\right) \delta=9.82-9.79(\mathrm{~d}, J=7.2 \mathrm{~Hz}, 1 \mathrm{H}), 7.77$ (s, 1H), 7.76-7.64 (m, 5H), 6.81-6.77 (m, 1H), 4.41-4.33 (q, $J=7.2 \mathrm{~Hz}, 2 \mathrm{H}), 3.99$ (s, $3 \mathrm{H}), 1.43-1.38(\mathrm{t}, J=7.2$ $\mathrm{Hz}, 3 \mathrm{H})$. LC-MS (ESI, Positive): $m / \approx(\mathrm{M}+\mathrm{H})^{+}=349.2$; Anal. calculated for $\mathrm{C}_{20} \mathrm{H}_{16} \mathrm{~N}_{2} \mathrm{O}_{4}: \mathrm{C}, 68.96 ; \mathrm{H}, 4.63 ; \mathrm{N}$, 8.04; Found: C, 68.82: H, 4.61: N, 8.07.

\section{Ethyl 3-(4-cyanobenzoyl)-7-methoxy-2- methylindolizine-1-carboxylate (2b)}

Appearance: Light yellow colour crystalline compound; IR (neat cm $\left.{ }^{-1}\right): 2231,1689,1631,1591 ;{ }^{1} \mathrm{H}-\mathrm{NMR}(400 \mathrm{MHz}$, $\left.\mathrm{CDCl}_{3}\right) \delta=9.58-9.56(\mathrm{~d}, J=7.6 \mathrm{~Hz}, 1 \mathrm{H}), 7.79(\mathrm{~s}, 1 \mathrm{H})$, 7.78-7.76 (d, $J=6.4 \mathrm{~Hz} 4 \mathrm{H}), 7.72-7.70(\mathrm{~d}, J=6.4 \mathrm{~Hz}$, $1 \mathrm{H}), 6.71-6.69(\mathrm{~m}, 1 \mathrm{H}), 4.39-4.34$ (q, $J=7.2 \mathrm{~Hz}, 2 \mathrm{H})$, 3.95 (s, 3H), 2.11 (s, $3 \mathrm{H}), 1.42-1.39(\mathrm{t}, J=7.2 \mathrm{~Hz}, 3 \mathrm{H})$; LC-MS (ESI, Positive): $m / \gtrless:(\mathrm{M}+\mathrm{H})^{+}=363.12$; Anal. calculated for $\mathrm{C}_{21} \mathrm{H}_{18} \mathrm{~N}_{2} \mathrm{O}_{4}: \mathrm{C}, 69.60 ; \mathrm{H}, 5.07 ; \mathrm{N}, 7.73$; Found : C, 69.59: H, 4.98: N, 7.79.

\section{Ethyl 3-(4-fluorobenzoyl)-7-methoxyindolizine-1- carboxylate (2c)}

Appearance: Light brown colour crystalline compound; IR (neat cm ${ }^{-1}$ ): 1695, 1641, 1614; ${ }^{1} \mathrm{H}-\mathrm{NMR}(300 \mathrm{MHz}$, $\left.\mathrm{CDCl}_{3}\right) \delta=9.79-9.77(\mathrm{~d}, J=7.5 \mathrm{~Hz}, 1 \mathrm{H}), 7.85-7.80$ (m, 2H), $7.73(\mathrm{~s}, 1 \mathrm{H}), 7.68(\mathrm{~s}, 1 \mathrm{H}), 7.26-7.15(\mathrm{~m}, 2 \mathrm{H})$, 7.25-7.21 (t, $J=8.4 \mathrm{~Hz}, 2 \mathrm{H}), 6.78-6.75(\mathrm{~m}, 1 \mathrm{H}), 4.37-4.33$ (q, $J=7.2 \mathrm{~Hz}, 2 \mathrm{H}), 3.97$ (s, 3H), 1.41-1.36 (t, $J=7.2 \mathrm{~Hz}$, 3H); LC-MS (ESI, Positive): $m / z:(\mathrm{M}+\mathrm{H})^{+} 342.2$; Anal. calculated for $\mathrm{C}_{19} \mathrm{H}_{16} \mathrm{FNO}_{4}$ : C, 66.86; $\mathrm{H}, 4.72 ; \mathrm{N}, 4.10$; Found : C, 66.82: H, 4.81: N, 3.99. 

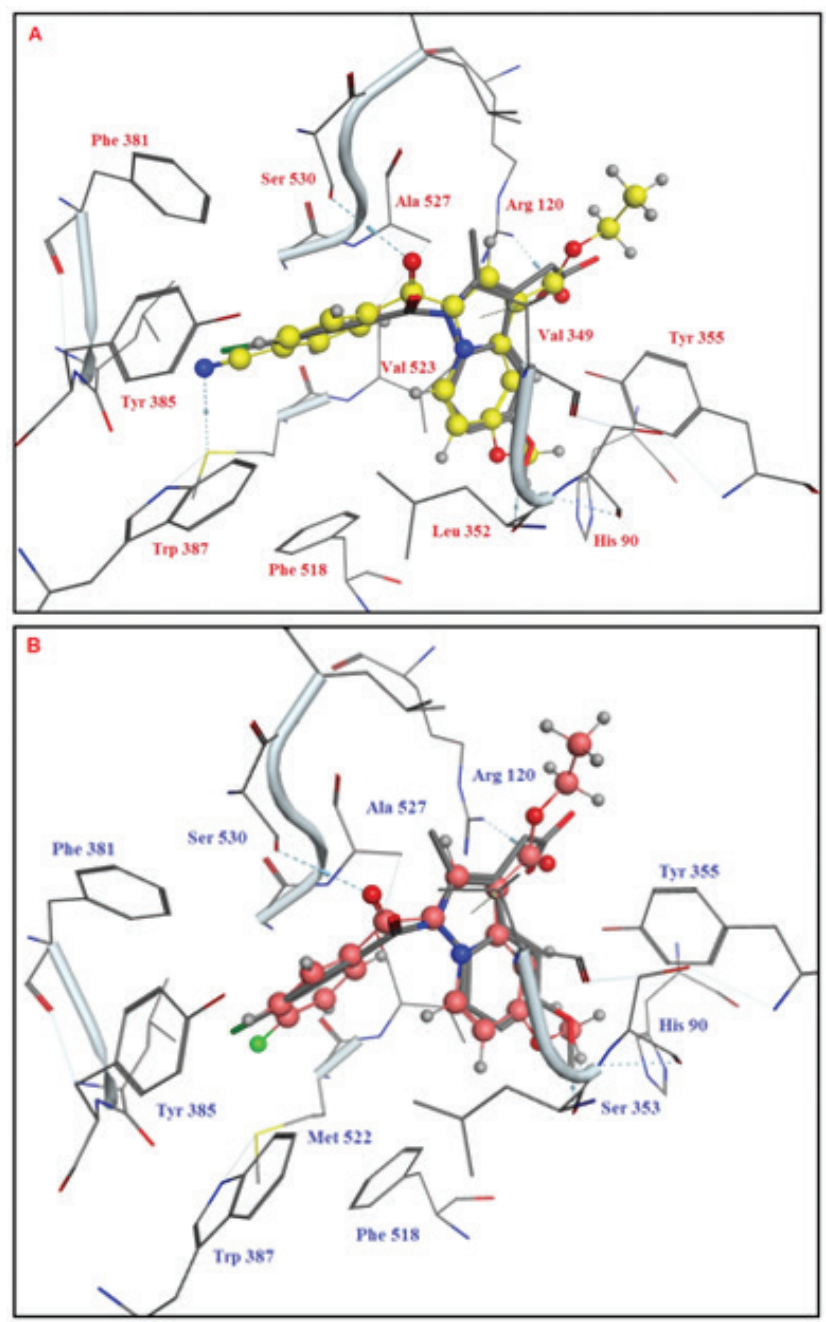

Figure 1: A) Binding mode of compound 2a in yellow colour superimposed with Indomethacin (elemental). B) Binding mode of compound $2 \mathrm{c}$ in pink colour superimposed with Indomethacin (elemental).

The analysis of the best poses of compounds $2 \mathrm{a}$ and $2 \mathrm{c}$ it was obvious that the compounds showed hydrogen bond formed by its benzoyl $\mathrm{C}=\mathrm{O}$ group which was close to Ser 530 hydroxyl group than that of Indomethacin. The carboxylate $\mathrm{C}=\mathrm{O}$ formed another hydrogen bond with $\mathrm{Arg} 120$ with distance $2.98 \mathrm{~A}^{\circ}$ when compared with that of Indomethacin $3.04 \mathrm{~A}^{\circ}$. The present of nitrile group at the para position of 2a allows dipole interactions with Met 522. The synthesized compounds do not have any hydrophilic side chains like Celecoxib and when Celecoxib was docked in COX-2 it showed different interaction pattern (Figure 2)

\section{Ethyl 3-(4-fluorobenzoyl)-7-methoxy-2- methylindolizine-1-carboxylate (2d)}

Appearance: Light brown colour crystalline compound; IR (neat $\mathrm{cm}^{-1}$ ): 1672, 1641, 1602; ${ }^{1} \mathrm{H}-\mathrm{NMR}(300 \mathrm{MHz}$, $\left.\mathrm{CDCl}_{3}\right) \delta=9.41-9.39(\mathrm{~d}, J=7.8 \mathrm{~Hz}, 1 \mathrm{H}), 7.76-7.68$ $(\mathrm{m}, 3 \mathrm{H}), 7.17-7.14(\mathrm{~m}, 2 \mathrm{H}), 6.68-6.64(\mathrm{~m}, 1 \mathrm{H}), 4.42-4.35$ (q, $J=7.2 \mathrm{~Hz}, 2 \mathrm{H}), 3.96(\mathrm{~s}, 3 \mathrm{H}), 2.19$ (s, 3H), 1.451.40 (t, $J=7.2 \mathrm{~Hz}, 3 \mathrm{H}$ ); LC-MS (ESI, Positive): $m / ₹$ : $(\mathrm{M}+\mathrm{H})^{+}$356.2; Anal. calculated for $\mathrm{C}_{20} \mathrm{H}_{18} \mathrm{FNO}_{4}$; C, 67.60; H, 5.11; N, 3.94; Found; C, 67.56; H, 5.16; N, 3.88 .

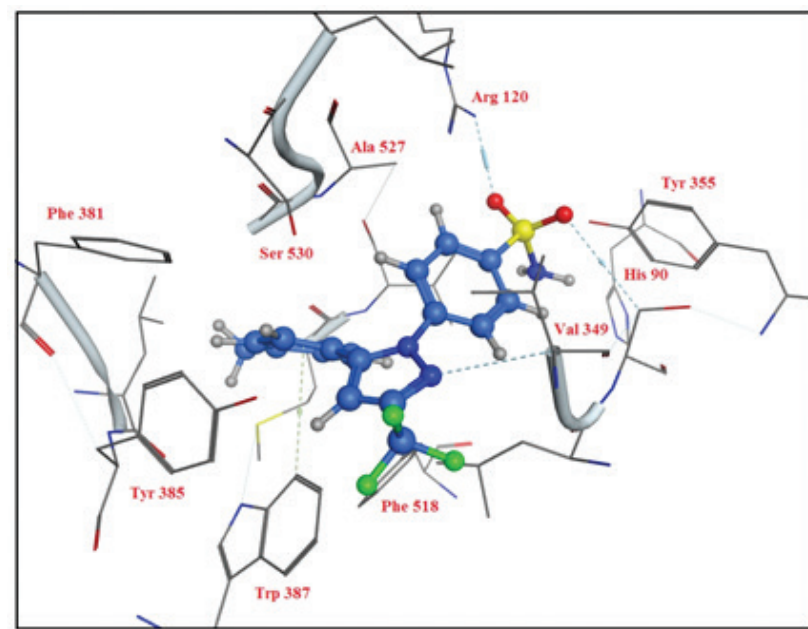

Figure 2: Binding mode of Celecoxib in COX-2 binding site. It showed hydrogen bond between Arg 120 and the sulfonyl oxygen. The second oxygen atom of sulfonyl group showed a hydrogen bond with His 90. According to the previous docking results, it was clear that the structure similarity with Indomethacin allows the indolizine to share the same binding mode. However, they have different structural features like; the absence of methylene group attached to carboxylic moiety in Indomethacin and that was a feature in making their $\mathrm{C}=\mathrm{O}$ group close to $\operatorname{Arg} 120$.

The position of nitrogen atom in indole scaffold is different than that of indolizine which allow the conformation of the indolizine to be in its stable form in the cis conformation (Figure 3 ).

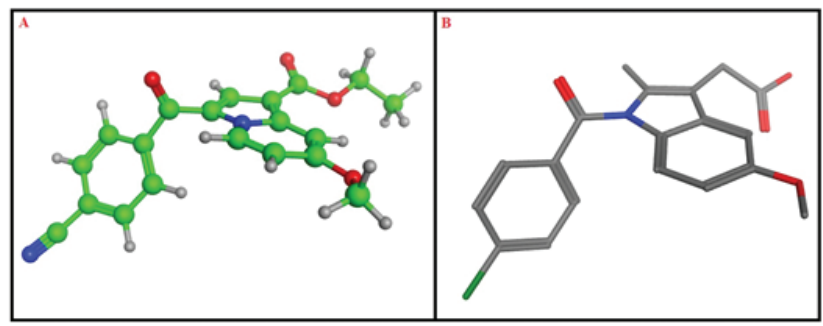

Figure 3: Comparison of the stable conformations of both A) indolizine active analogue $2 a$ and $B$ ) Indomethacin.

\section{Ethyl 2-ethyl-3-(4-fluorobenzoyl)-7- methoxyindolizine-1-carboxylate (2e)}

Appearance: Light yellow colour crystalline compound; IR (neat $\left.\mathrm{cm}^{-1}\right)$ : 1668, 1641, 1591; ${ }^{1} \mathrm{H}-\mathrm{NMR}(400 \mathrm{MHz}$, $\left.\mathrm{CDCl}_{3}\right) \delta=9.25-9.23(\mathrm{~d}, J=7.6 \mathrm{~Hz}, 1 \mathrm{H}), 7.76(\mathrm{~s}, 1 \mathrm{H})$, 7.70-7.67 (m, 2H), 7.17-7.12 (m, 2H), 6.64-6.61 (m, 1H), $4.40-4.35$ (q, $J=7.2 \mathrm{~Hz}, 2 \mathrm{H}), 3.94(\mathrm{~s}, 3 \mathrm{H}), 2.68-2.62$ $(\mathrm{q}, J=7.2 \mathrm{~Hz}, 2 \mathrm{H}), 1.43-1.39(\mathrm{t}, J=7.2 \mathrm{~Hz}, 3 \mathrm{H}), 1.00-$ 0.97 (t, $J=7.2 \mathrm{~Hz}, 3 \mathrm{H}$ ); LC-MS (ESI, Positive): $\mathrm{m} / \mathrm{z}$ $(\mathrm{M}+\mathrm{H})^{+}=370.12$; Anal. calculated for $\mathrm{C}_{21} \mathrm{H}_{20} \mathrm{FNO}_{4}$ : C, 68.28; H, 5.46; N, 3.79; Found: C, 68.29: H, 5.47: N, 3.71 .

\section{Ethyl 3-(4-bromobenzoyl)-7-methoxyindolizine-1- carboxylate (2f)}

Appearance: Light brown colour crystalline compound; IR (neat $\mathrm{cm}^{-1}$ ): 1699, 1647, 1606; ${ }^{1} \mathrm{H}-\mathrm{NMR}(300 \mathrm{MHz}$, 
$\left.\mathrm{CDCl}_{3}\right) \delta=9.82-9.79(\mathrm{~d}, J=7.2 \mathrm{~Hz}, 1 \mathrm{H}), 7.89-7.86$ $(\mathrm{m}, 2 \mathrm{H}), 7.83-7.75(\mathrm{~m}, 4 \mathrm{H}), 7.62(\mathrm{~s}, 1 \mathrm{H}), 6.82-6.78(\mathrm{~m}, 1 \mathrm{H})$, 4.39-4.34 (q, $J=7.2 \mathrm{~Hz}, 2 \mathrm{H}$ ), 3.98 (s, 3H), 1.41-1.35 $(\mathrm{t}, J=7.2 \mathrm{~Hz}, 3 \mathrm{H})$; LC-MS (ESI, Positive): $m / \gtrless(\mathrm{M}+\mathrm{H})^{+}$ 402.2, 404.4; Anal. calculated for $\mathrm{C}_{19} \mathrm{H}_{16} \mathrm{BrNO}_{4}$ : C, 56.73; H, 4.01; N, 3.48; Found : C, 56.72: H, 3.97: N, 3.49 .

\section{Ethyl 3-(4-bromobenzoyl)-7-methoxy-2- methylindolizine-1-carboxylate $(2 \mathrm{~g})$}

Appearance: Light brown colour crystalline compound; IR (neat $\left.\mathrm{cm}^{-1}\right)$ : 1697, 1670, 1639; ${ }^{1} \mathrm{H}-\mathrm{NMR}(300 \mathrm{MHz}$, $\left.\mathrm{CDCl}_{3}\right) \delta=9.44-9.41(\mathrm{~d}, J=7.5 \mathrm{~Hz}, 1 \mathrm{H}), 7.74-7.51(\mathrm{~m}$, $5 \mathrm{H}), 6.67-6.64(\mathrm{~m}, 1 \mathrm{H}), 4.40-4.33$ (q, $J=7.2 \mathrm{~Hz}, 2 \mathrm{H})$, 3.94 (s, 3H), 2.17 (s, 3H), 1.43-1.38 (t, $J=7.2 \mathrm{~Hz}, 3 \mathrm{H})$; LC-MS (ESI, Positive): $m / z(\mathrm{M}+\mathrm{H})^{+}=416.2,418.2$; Anal. calculated for $\mathrm{C}_{20} \mathrm{H}_{18} \mathrm{BrNO}_{4}$ : C, 57.71; $\mathrm{H}, 4.36 ; \mathrm{N}$, 3.36; Found: C, 57.76; H, 4.31; N, 3.37.

\section{Ethyl 7-methoxy-3-(3-methoxybenzoyl)indolizine- 1 -carboxylate $(2 \mathrm{~h})$}

Appearance: Light brown colour crystalline compound; IR (neat cm ${ }^{-1}$ ): 1696, 1672, 1645, 1608; ${ }^{1} \mathrm{H}-\mathrm{NMR}(300$ $\left.\mathrm{MHz}, \mathrm{CDCl}_{3}\right) \delta=9.82-9.79(\mathrm{~d}, J=7.2 \mathrm{~Hz}, 1 \mathrm{H}), 7.74(\mathrm{~s}$, $1 \mathrm{H}), 7.44-7.31(\mathrm{~m}, 4 \mathrm{H}), 7.12-7.08(\mathrm{~m}, 1 \mathrm{H}), 6.78-6.74(\mathrm{~m}$, $1 \mathrm{H}), 4.38-4.33$ (q, $J=7.2 \mathrm{~Hz}, 2 \mathrm{H}) 3.96$ (s, 3H), 3.87 (s, 3H) $1.40-1.35$ (t, $J=7.2 \mathrm{~Hz}, 3 \mathrm{H}$ ); LC-MS (ESI, Positive): $m / z(\mathrm{M}+\mathrm{H})^{+}=354.2$; Anal. calculated for $\mathrm{C}_{20} \mathrm{H}_{19} \mathrm{NO}_{5}$; C, 67.98; H, 5.42; N, 3.96; Found; C, 67.95; H, 5.44; N, 3.93.

\section{Ethyl 7-methoxy-3-(3-methoxybenzoyl)-2- methylindolizine-1-carboxylate (2i)}

Appearance: Light brown colour crystalline compound; IR (neat $\mathrm{cm}^{-1}$ ): 1701, 1666, 1641, 1598; ${ }^{1} \mathrm{H}-\mathrm{NMR}(300$ $\left.\mathrm{MHz}, \mathrm{CDCl}_{3}\right) \delta=9.47-9.44(\mathrm{~d}, J=7.8 \mathrm{~Hz}, 1 \mathrm{H}), 7.76$ (s, 1H), 7.41-7.38 (m, 1H), 7.38-7.24 (m, 2H), 7.11-7.08 $(\mathrm{m}, 1 \mathrm{H}), 6.68-6.65(\mathrm{~m}, 1 \mathrm{H}), 4.42-4.37$ (q, $J=7.2 \mathrm{~Hz}$, 2H), 3.96 (s, 3H), 3.87 (s, 3H), 2.20 (s, 3H), 1.45-1.40 (t, $J=7.2 \mathrm{~Hz}, 3 \mathrm{H})$; LC-MS (ESI, Positive): $m / z(\mathrm{M}+\mathrm{H})^{+}=$ 368.2; Anal. calculated for $\mathrm{C}_{21} \mathrm{H}_{21} \mathrm{NO}_{5} ; \mathrm{C}, 68.56 ; \mathrm{H}, 5.76$; N, 3.81; Found; C, 68.54; H, 5.78; N, 3.79.

\section{In vitro COX-2 inhibition activity}

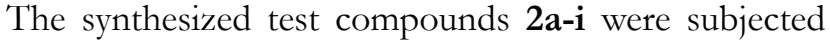
for in vitro human recombinant COX-2 enzyme inhibitory activity using an enzyme immunoassay (EIA) kit according to a reported literature..$^{62-64}$

\section{Molecular docking with MOE 20.13.08}

Molecular Operating Environment (MOE) 2013.08 package license was purchased from Chemical Computing Group Inc, Sherbooke St, Montreal, QC, Canada, ${ }^{65}$ All the test compounds were built and saved as .MOE files. Rigid receptor was used as a docking protocol. Both receptor-solvent were kept as a "receptor". Triangle matcher was used as a placement method. Two rescoring were computed, rescoring 1 was selected as London dG. Rescoring 2 was selected as affinity. Force field was used as a refinement.

\section{Statistical analysis}

Comparison of In vitro COX-2 inhibitory activity of indolizine analogs with selective (Celecoxib) and nonselective (Indomethacin) standard compounds were carried out using one-way investigation of variance (ANOVA) that examined the main effect of treatment (ethyl 7-methoxy-3-(substitutredbenzoyl)-2-substitutedindolizine-1-carboxylate analogues 2a-i, Celecoxib and Indomethacin) on values of $\mathrm{IC}_{50}$. Bonferroni test was used for post hoc analysis to account for the increased possibility of type I error. ${ }^{66}$ Before ANOVA testing, data were transformed to ranks ${ }^{67}$ to fit better the assumptions of the test. In all cases, a value of $\mathrm{p}<0.05$ was considered statistically significant.

\section{RESULTS AND DISCUSSION}

Scheme-1 describes the general route to obtain the title compounds $\mathbf{2 a - i}$. Intermediate compounds $\mathbf{1 a - d}$ were prepared by stirring 4-methoxylpyridine with substituted phenacyl bromides separately in the presence of acetone medium at room temperature as shown in step-I of Scheme-1. The reaction completion was monitored on Thin Layer Chromatography (TLC) and after completion of the reaction, the solid deposited was filtered, dried at room temperature and recrystallized using ethanol as solvent. NMR and LC-MS method was used to characterize the compounds 1a-d and yields obtained were in the range of $98-99 \%$.

Substituted indolizine analogues $\mathbf{2 a - i}$ have been prepared by the reaction between 4-methoxy-1-(2-(substituted phenyl)-2-oxoethyl)pyridin-1-ium bromide and substituted alkynes in dimethylformamide medium in presence of anhydrous potassium carbonate as depicted in step-II of Scheme-1. The completion of the reaction was monitored on TLC and all the products have been achieved within 30 min with constant stirring. The products were purified by column chromatography using 60-120 mesh silica gel using $n$-hexane - ethyl acetate as a solvent and the yield was found to be $68-80 \%$. IR, NMR, LC-MS and elemental analysis methods were used to characterize the compounds 2a-i. ChemBioDraw Ultra 13.0v was used to calculate $c \log P$ of the compounds and the values were in the range of 3.9570-5.7483. 


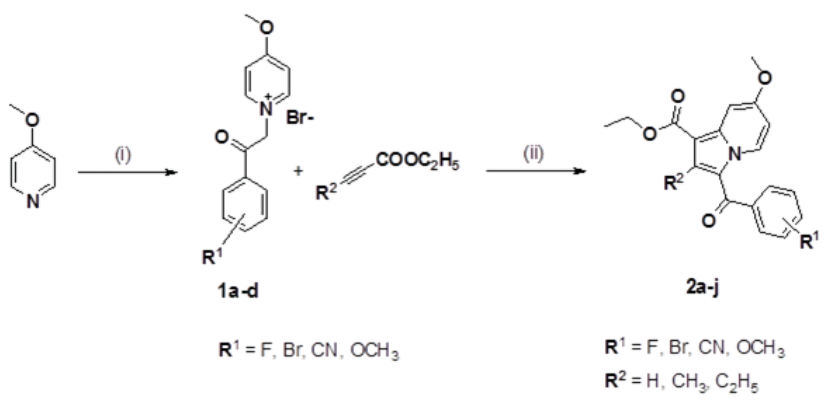

Scheme 1: Reagents and conditions: (i) substituted phenacyl bromide, acetone, $5 \mathrm{~h}$, stir at room temperature; (ii) $\mathrm{K}_{2} \mathrm{CO}_{3}$, DMF, stir at room temperature, $30 \mathrm{~min}$.

\section{CONCLUSION}

The reactions performed to obtain indolizine analogues 2a-i are eco-friendly as they are carried out at room temperature with satisfactory yield. The compounds 2 a and $2 \mathrm{c}$ emerged as promising compounds for COX-2 inhibition from the series when compared to standard substances Indomethacin and Celecoxib, which is also authenticated with docking studies.

\section{ACKNOWLEDGEMENT}

We are thankful to Sahyadri Science College, National Research Foundation (96807), South Africa and Durban University of Technology for support and facilities.

\section{SUPPLEMENTARY DATA}

Supplementary data related to this article can be found as attachment.

\section{COMPETING INTERESTS}

The authors declare that they have no competing interests.

\section{CONFLICT OF INTEREST}

The authors declare that they have no competing interests.

\section{ABBREVIATION USED}

COX: Cyclooxygenase enzyme; NMR: Nuclear magnetic resonance; TLC: Thin layer chromatography; LC-MS: Liquid chromatography-mass spectrometry.

\section{REFERENCES}

1. Flitsch W. Comprehensive Heterocyclic Chemistry. Katritzky, A R, Ress, C W, Eds; Pergamon: Oxford. 1984;3:443-70.

2. Tielmann P, Hoenke C. Optimisation, scope and limitations of the synthesis of 5-aminoindolizines from oxazolo[3,2-a]pyridinium salts. Tetrahedron Lett. 2006;47(3):261-5. https://doi.org/10.1016/j.tetlet.2005.11.033.
3. Sandeep C, Venugopala KN, Mohammed AK, et al. Review on chemistry of natural and synthetic indolizines with their chemical and pharmacological properties. J Basic Clin Pharm. 2016; In press.

4. Bode ML, Kaye PT. Indolizine studies. Part 2. Synthesis and NMR spectroscopic analysis of 2-substituted indolizines. J Chem Soc, Perkin Trans 1. 1993(15):1809-13. https://doi.org/10.1039/p19930001809.

5. Nikolai SP, Baktibaev OB. Indolizines. Russ Chem Rev. 1975;44(9):748. https://doi.org/10.1070/RC1975v044n09ABEH002374.

6. Mosby WL. Heterocyclic Systems with Bridgehead Nitrogen Atom. Interscience: New York, NY. 1961;Part I:239.

7. Borrows ET, Holland DO. The Chemistry of the Pyrrocolines and the Octahydropyrrocolines. Chemical Reviews. 1948/06/01 1948;42(3):611-43.

8. Michael JP. Simple indolizidine and quinolizidine alkaloids. Alkaloids Chem Biol. 2001;55:91-258. https://doi.org/10.1016/S0099-9598(01)55004-X.

9. Michael JP. Indolizidine and quinolizidine alkaloids. Nat Prod Rep. 2007;24(1):191-222. https://doi.org/10.1039/b509525p PMid:17268613.

10. Michael JP. Indolizidine and quinolizidine alkaloids. Nat Prod Rep. 2008;25(1):139-65. https://doi.org/10.1039/B612166G PMid:18250900.

11. Molyneux RJ, James LF. Loco intoxication: indolizidine alkaloids of spotted locoweed (Astragalus lentiginosus). Science. 1982;216(4542):190-1. https:// doi.org/10.1126/science.6801763.

12. Hagishita S, Yamada M, Shirahase $\mathrm{K}$, et al. Potent inhibitors of secretory phospholipase A2: synthesis and inhibitory activities of indolizine and indene derivatives. J Med Chem. 1996;39(19):3636-58. https://doi.org/10.1021/ jm960395q PMid:8809154.

13. Millet R, Domarkas J, Rigo B, et al. Novel potent substance $P$ and neurokinin A receptor antagonists. Conception, synthesis and biological evaluation of indolizine derivatives. Bioorg Med Chem. 2002/09// 2002;10(9):2905-12.

14. Weide T, Arve L, Prinz H, Waldmann H, Kessler H. 3-Substituted indolizine1-carbonitrile derivatives as phosphatase inhibitors. Bioorg Med Chem Lett. 2006;16(1):59-63. https://doi.org/10.1016/j.bmcl.2005.09.051 PMid:16236508.

15. James DA, Koya K, Li H, et al. Indole- and indolizine-glyoxylamides displaying cytotoxicity against multidrug resistant cancer cell lines. Bioorg Med Chem Lett. 2008;18(6):1784-7. https://doi.org/10.1016/j.bmcl.2008.02.029 PMid:18308566

16. Oslund RC, Cermak N, Gelb MH. Highly specific and broadly potent inhibitors of mammalian secreted phospholipases A2. J Med Chem. 2008;51(15):4708-14. https://doi.org/10.1021/jm800422v PMid:18605714 PMCid:PMC2965735.

17. Beck EM, Hatley R, Gaunt MJ. Synthesis of rhazinicine by a metalcatalyzed $\mathrm{C}-\mathrm{H}$ bond functionalization strategy. Angew Chem Int Ed Engl. 2008;47(16):3004-7. https://doi.org/10.1002/anie.200705005 PMid:18338359.

18. Wei $X, \mathrm{Hu} Y, \mathrm{Li}$ T, Hu H. A facile one-step synthesis of aromatic indolizines by 1,3-dipolar cycloaddition of pyridinium and related heteroaromatic ylides with alkenes in the presence of TPCD [Copy4(HCrO4)2]. J Chem Soc, Perkin Trans 1. 1993(20):2487-9. https://doi.org/10.1039/p19930002487.

19. Uchida T, Matsumoto K. Methods for the Construction of the Indolizine Nucleus*. Synthesis. 03.04.2002 1976;1976(04):209-36.

20. Seregin IV, Gevorgyan V. Direct transition metal-catalyzed functionalization of heteroaromatic compounds. Chem Soc Rev. 2007;36(7):1173-93. https:// doi.org/10.1039/b606984n PMid:17576484 PMCid:PMC3674790.s

21. Shen Y-M, Grampp G, Leesakul N, Hu H-W, Xu J-H. Synthesis and Emitting Properties of the Blue-Light Fluorophores Indolizino[3,4,5-ab] isoindole Derivatives. Eur J Org Chem. 2007;2007(22):3718-26. https://doi. org/10.1002/ejoc.200700250

22. Schwier T, Sromek AW, Yap DM, Chernyak D, Gevorgyan V. Mechanistically diverse copper-, silver-, and gold-catalyzed acyloxy and phosphatyloxy migrations: efficient synthesis of heterocycles via cascade migration/ cycloisomerization approach. J Am Chem Soc. 2007;129(32):9868-78. https://doi.org/10.1021/ja072446m PMid:17658805 PMCid:PMC2536635

23. Seregin IV, Schammel AW, Gevorgyan V. Base and ligand-free roomtemperature synthesis of $\mathrm{N}$-fused heteroaromatic compounds via the transition metal-catalyzed cycloisomerization protocol. Org Lett. 2007/08/01 2007;9(17):3433-6.

24. Yan B, Liu Y. Gold-catalyzed multicomponent synthesis of aminoindolizines from aldehydes, amines, and alkynes under solvent-free conditions or in water. Org Lett. 2007/10/01 2007;9(21):4323-6. 
25. Chuprakov S, Gevorgyan V. Regiodivergent metal-catalyzed rearrangement of 3-iminocyclopropenes into $\mathrm{N}$-fused heterocycles. Org Lett. 2007/10/01 2007;9(22):4463-6.

26. $\mathrm{Xu} \mathrm{T,} \mathrm{Alper} \mathrm{H.} \mathrm{Synthesis} \mathrm{of} \mathrm{indolizine} \mathrm{derivatives} \mathrm{by} \mathrm{Pd-catalyzed} \mathrm{oxidative}$ carbonylation. Org Lett. 2015/09/18 2015;17(18):4526-9.

27. Yan B, Zhou Y, Zhang H, Chen J, Liu Y. Highly efficient synthesis of functionalized indolizines and indolizinones by copper-catalyzed cycloisomerizations of propargylic pyridines. J Org Chem. 2007;72(20):7783-6. https://doi.org/10.1021/jo070983j PMid:17718578

28. Zhou H, Danger DP, Dock ST, et al. Synthesis and SAR of benzisothiazoleand indolizine- $\beta$-d-glucopyranoside inhibitors of SGLT2. ACS Med Chem Lett. 2010;1(1):19-23. https://doi.org/10.1021/ml900010b PMid:24900169 PMCid:PMC4007969

29. Kim I, Choi J, Won HK, Lee GH. Expeditious synthesis of indolizine derivatives via iodine mediated 5-endo-dig cyclization. Tetrahedron Lett. 2007;48(39):6863-7. https://doi.org/10.1016/j.tetlet.2007.07.180

30. Guazzelli G, Settambolo R. 4-Indolylbutanals from rhodium-catalyzed hydroformylation of allylindoles as precursors of benzofused indolizines. Tetrahedron Lett. 2007;48(34):6034-8. https://doi.org/10.1016/j.tetlet.2007.06.076

31. $\mathrm{Hu} \mathrm{H}, \mathrm{Li} \mathrm{G}, \mathrm{Hu} \mathrm{W}$, et al. Synthesis of pyrrolo[2,1,5-cd]indolizines through dehydrogenative Heck Annelation of indolizines with diaryl acetylenes using dioxygen as an oxidant. Org Lett. 2015/03/06 2015;17(5):1114-7.

32. Xia J-B, You S-L. Synthesis of 3-haloindolizines by Copper(II) halide mediated direct functionalization of indolizines. Organic Lett. 2009/03/05 2009;11(5):1187-90.

33. Chernyak D, Gadamsetty SB, Gevorgyan V. Low temperature organocoppermediated two-component cross coupling/cycloisomerization approach toward N-fused heterocycles. Organic Lett. 2008/06/05 2008;10(11):2307-10.

34. Rogers BN, Piotrowski DW, Walker DP, et al. PCT Int. Appl. WO 2003070732. 2003.

35. Vaught JL, Carson JR, Carmosin RJ, et al. Antinociceptive action of McN-5195 in rodents: a structurally novel (indolizine) analgesic with a nonopioid mechanism of action. J Pharmacol Exp Ther. 1990;255(1):1-10. PMid:2170621

36. Das AK, Som S. Synthesis and evaluation of some 3-benzoylindolizine-1carboxamides as possible anti-inflammatory and analgesic agents. Orient $\mathrm{J}$ Chem. 2006;2(22):415-20.

37. Kallay KR, Doerge RF. p-Substituted 1,2-diphenylindolizines as antiinflammatory agents. J Pharm Sci. 1972;61(6):949-51. https://doi. org/10.1002/jps.2600610629

38. Bermudez J, Fake CS, Joiner GF, et al. 5-Hydroxytryptamine (5-HT3) receptor antagonists. 1. Indazole and indolizine-3-carboxylic acid derivatives. J Med Chem. 1990;33(7):1924-9. https://doi.org/10.1021/jm00169a016 PMid:2362270

39. Antonini I, Claudi F, Gulini U, Micossi L, Venturi F. Indolizine derivatives with biological activity IV: 3-(2-Aminoethyl)-2-methylindolizine, 3-(2-aminoethyl)2-methyl-5,6,7,8-tetrahydroindolizine, and their $\mathrm{N}$-alkyl derivatives. J Pharm Sci. 1979;68(3):321-4. https://doi.org/10.1002/jps.2600680317 PMid:423120

40. Sandeep C, Padmashali B, Venugopala KN, Kulkarni RS, Venugopala R, Odhav B. Synthesis and characterization of ethyl 7-acetyl-2-substituted 3-(substituted benzoyl)indolizine-1-carboxylates for in vitro anticancer activity. Asian J Chem. 2016;28(5):1043-8. https://doi.org/10.14233/ ajchem.2016.19582

41. Wall ME, Wani MC, Cook CE, Palmer KH, McPhail AT, Sim GA. Plant antitumor agents. I. The isolation and structure of Camptothecin, a novel alkaloidal leukemia and tumor inhibitor from Camptotheca acuminate. J Am Chem Soc. 1966/08/01 1966;88(16):3888-90.

42. Wani MC, Nicholas AW, Wall ME. Plant antitumor agents. 28. Resolution of a key tricyclic synthon, 5'(RS)-1,5-dioxo-5'-ethyl-5'-hydroxy-2' $\mathrm{H}, 5^{\prime} \mathrm{H}, 6^{\prime} \mathrm{H}$ 6'-oxopyrano[3' ,4'- f]delta 6,8-tetrahydro-indolizine: total synthesis and antitumor activity of 20(S)- and 20(R)-camptothecin. J Med Chem. 1987;30(12):2317-9. https://doi.org/10.1021/jm00395a024PMid:3681902

43. Jorgensen AS, Jacobsen P, Christiansen LB, et al. Synthesis and estrogen receptor binding affinities of novel pyrrolo[2,1,5-cd]indolizine derivatives. Bioorg Med Chem Lett. 2000;10(20):2383-6. https://doi.org/10.1016/S0960894X(00)00474-1

44. Dinica RM, Furdui B, Ghinea IO, Bahrim G, Bonte S, Demeunynck M. Novel One-Pot Green Synthesis of Indolizines Biocatalysed by Candida antarctica
Lipases. Mar Drugs. 2013;11(2):431-9. https://doi.org/10.3390/md11020431 PMid:23389089 PMCid:PMC3640390

45. Singh GS, Mmatli EE. Recent progress in synthesis and bioactivity studies of indolizines. Eur J Med Chem. 2011;46(11):5237-57. https://doi.org/10.1016/j. ejmech.2011.08.042 PMid:21937153

46. Lins CL, Block JH, Doerge RF. Nitro- para- and meta-substituted 2-phenylindolizines as potential antimicrobial agents. J Pharm Sci. May 1982;71(5):556-61. https://doi.org/10.1002/jps.2600710519 PMid:7047715

47. Olejníková P, Birošová L. Antimicrobial and antimutagenic properties of newly synthesized derivatives of indolizine. Sci Pharm. 2009;77:216. https:// doi.org/10.3797/scipharm.oephg.21.PO-17

48. Harrell WB, Doerge RF. New compounds: Mannich bases from 2-phenylindolizines II. 3-dialkylaminomethyl derivatives. J Pharm Sci. 1967;56(9):1200-2. https://doi.org/10.1002/jps.2600560939 PMid:6058233

49. De AU, Saha BP. Indolizines II: search for potential oral hypoglycemic agents. J Pharm Sci. 1975;64(2):49-45. https://doi.org/10.1002/jps.2600640211 PMid:236380

50. De AU, Saha BP. Search for potential oral hypoglycemic agents: synthesis and activity of 2-(N-alkylaminomethyl)indolizines. J Pharm Sci. 1973;62(11):1897-8. https://doi.org/10.1002/jps.2600621142

51. Kurumbail RG, Stevens AM, Gierse JK, et al. Structural basis for selective inhibition of cyclooxygenase-2 by anti-inflammatory agents. Nature. 1996;384(6610):644-8. https://doi.org/10.1038/384644a0 PMid:8967954

52. Harirforoosh S, Asghar W, Jamali F. Adverse effects of nonsteroidal antiinflammatory drugs: an update of gastrointestinal, cardiovascular and renal complications. J Pharm Pharm Sci. 2013;16(5):821-47. https://doi. org/10.18433/J3VW2F PMid:24393558

53. Fosslien E. Molecular pathology of cyclooxygenase-2 in neoplasia. Ann Clin Lab Sci. 2000;30(1):3-21. PMid:10678579

54. Panini P, Venugopala KN, Odhav B, Chopra D. Polymorphism in two biologically active dihydropyrimidinium hydrochloride derivatives: quantitative inputs towards the energetics associated with crystal packing. Acta Cryst B. 2014;70(4):681-96. https://doi.org/10.1107/S2052520614006209PMid:25080247

55. Nayak SK, Venugopala KN, Chopra D, Row TNG. Insights into conformational and packing features in a series of aryl substituted ethyl-6-methyl-4-phenyl2-oxo-1,2,3,4-tetrahydropyrimidine-5-carboxylates. CrystEngComm. 2011;13(2):591-605. https://doi.org/10.1039/C0CE00045K

56. Munshi P, Venugopala KN, Jayashree BS, Guru Row TN. Concomitant polymorphism in 3-acetylcoumarin: Role of weak $\mathrm{C}-\mathrm{H} \cdots \mathrm{O}$ and $\mathrm{C}-\mathrm{H} \cdots \pi$ interactions. Cryst Growth Des. 2004/11/01 2004;4(6):1105-7.

57. Venugopala KN, Govender R, Khedr MA, et al. Design, synthesis, and computational studies on dihydropyrimidine scaffolds as potential lipoxygenase inhibitors and cancer chemopreventive agents. Drug Des Devel Ther. 2015;9:911-21. https://doi.org/10.2147/DDDT.S73890 PMid:25733811 PMCid:PMC4338777

58. Venugopala KN, Krishnappa M, Nayak SK, et al. Synthesis and antimosquito properties of 2,6-substituted benzo[d]thiazole and 2,4-substituted benzo[d]thiazole analogues against Anopheles arabiensis. Eur J Med Chem. 2013;65:295-303. https://doi.org/10.1016/j.ejmech.2013.04.061 PMid:23727539

59. Sandeep C, Venugopala KN, Gleiser RM, et al. Greener synthesis of indolizine analogues using water as a base and solvent: study for larvicidal activity against Anopheles arabiensis. Chemical Biology \& Drug Design. 2016;88(6):899-904. https://doi.org/10.1111/cbdd.12823 PMid:27440719

60. Venugopala KN, Nayak SK, Pillay M, Prasanna R, Coovadia YM, Odhav B. Synthesis and antitubercular activity of 2-(substituted phenyl/benzyl-amino)6-(4-chlorophenyl)-5-(methoxycarbonyl)-4-methyl-3,6-dihydropyrimidin1-ium chlorides. Chem Biol Drug Des. 2013;81(2):219-27. https://doi. org/10.1111/cbdd.12065 PMid:23150983

61. Leeson P. Drug discovery: Chemical beauty contest: Nature. 2012 Jan 25;481(7382):455-6. doi: 10.1038/481455a. https://doi.org/10.1038/481455a

62. Hinz B, Cheremina O, Brune K. Acetaminophen (paracetamol) is a selective cyclooxygenase-2 inhibitor in man. FASEB J. 2008;22(Copyright (C) 2016 American Chemical Society (ACS). All Rights Reserved.):383-390, 310.1096/ fj.1007-8506com.

63. Ranatunge RR, Earl RA, Garvey DS, et al. 3-(2-Methoxytetrahydrofuran-2yl)pyrazoles: a novel class of potent, selective cyclooxygenase-2 (COX-2) 
inhibitors. Bioorg Med Chem Lett. 2004;14(Copyright (C) 2016 American Chemical Society (ACS). All Rights Reserved.):6049-52.

64. Wuest F, Tang X, Kniess T, Pietzsch J, Suresh M. Synthesis and cyclooxygenase inhibition of various (aryl-1,2,3-triazole-1-yl)-methanesulfonylphenyl derivatives. Bioorg Med Chem. 2009;17(Copyright (C) 2016 American Chemical Society (ACS). All Rights Reserved.):1146-1151.

65.

2013.08. 1010 Sherbooke St. West, Suite \#910, Montreal, QC, Canada, H3A

2R7: Chemical Computing Group Inc.; 2014.

66.

InfoStat versión, Grupo InfoStat, FCA, . Universidad Nacional de Córdoba Argentina. 2014.
67. Shirley EA. Application of ranking methods to multiple comparison procedures and factorial experiments. Appl Statist. 1987;36:205-13. https:// doi.org/10.2307/2347552

68. Loll PJ, Picot D, Ekabo O, Garavito RM. Synthesis and Use of lodinated Nonsteroidal Antiinflammatory Drug Analogs as Crystallographic Probes of the Prostaglandin H2 Synthase Cyclooxygenase Active Site. Biochemistry. 1996/01/01 1996;35(23):7330-7340.

69. Sethi R, Arora S, Saini D, Jain S. Synthesis, characterization, molecular docking studies and antimicrobial evaluation of $\mathrm{N}$-benzimidazol-1-yl-methylbenzamide derivatives. INDIAn Journal of Pharmaceutical Education and Research. 2016;50(3):424-34. https://doi.org/10.5530/ijper.50.3.16

70. Kurumbail RG, Stevens AM, Gierse JK, et al. Structural basis for selective inhibition of cyclooxygenase-2 by anti-inflammatory agents. Nature. 1996;384(6610):644-48. https://doi.org/10.1038/384644a0 PMid:8967954

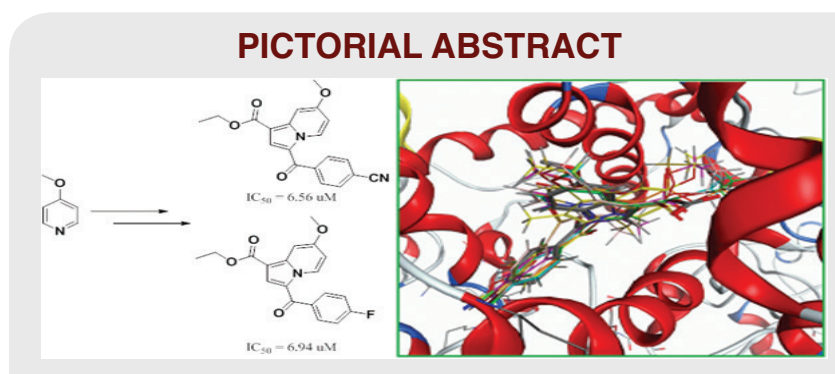

\section{SUMMARY}

- Design and synthesis of a new series of ethyl 7-methoxy-2-substituted-3-(substitutedbenzoyl) indolizine-1-carboxylates 2a-i was achieved by two step chemical reactions and screened for their invitro inhibitory activity against COX-2 enzyme.

- Compound $2 \mathrm{a}$ and $2 \mathrm{c}$ emerged as promising COX-2 enzyme inhibitor with $\mathrm{IC}_{50}$ of 6.56 and $6.94 \mu \mathrm{M}$, respectively from the synthesized series when compared to Celecoxib and Indomethacin as selective and nonselective standards, respectively.

\section{About Authors}

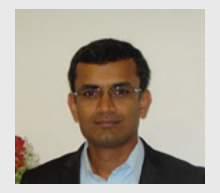

Dr. Katharigatta N. Venugopala: He is associated with Prof. Odhav's research group at Department of Biotechnology and Food Technology, Durban University of Technology, on identification of potential lead compounds from natural sources for anti-HIV, anti-mosquito and anti-TB properties, synthesis of novel heterocyclic compounds as anti-TB, anti-cancer, anti-inflammatory and antimosquito agents and development and screening of promising pharmacologically active compounds for polymorphism properties by single crystal X-ray studies.

Cite this article: Sandeep C, Venugopala KN, Khedr MA, Padmashali B, Kulkarni RS, Venugopala R, Odhav R. Design and Synthesis of Novel Indolizine Analogues as COX-2 Inhibitors: Computational Perspective and in vitro Screening. Indian J of Pharmaceutical Education and Research. 2017;51(3):452-60. 